\title{
16 ビット・ワンボードマイコンの利用
}

\section{——動物・生理実験の制御・計測と}

大型計算機のオンライン利用——

\author{
石井 \\ 巌* \\ APPLICATION OF 16 BIT ONE-BOARD MICROCOMPUTERS TO ANIMAL \\ PHYSIOLOGICAL EXPERIMENT AND COMPUTER COMMUNICATION
}

Iwao IsHII

This paper describes a one-board microcomputer system for the experimental study of animal physiological psychology. The system consists of three interconnected one-board microcomputers, I/O devices, interfaces for experimental apparatus, and an acoustic coupler. One of the three one-board microcomputers is Intel SDK- 85 which has 8 bit CPU. The other two are Hitachi H680 TRs which have 16 bit CPUs. Each of these microcomputers is assigned to its specialized sub-function of this system, and they operate concurrently. This is a low-cost optimized system. The system is used both for the control of experiment and the acquisition and primary processing of experimental data, and for the on-line communication with the computer centers through the acoustic coupler and the switched line; higher processing of data, software development, literature search, model development, etc. This system is low-cost, understandable, amenable to maintenance, expansible, and easy to connect with experimental apparatus.

マイクロ・コンピューターが諸研究に用いられてい る. マイコンを利用している研究分野が広がっている が, 用いられるマイコンの種類も多く, 利用の仕方も 多様である、筆者の属する心理学研究室にも, 颃なじ みの PC-8001 など数種のマイコンが使われているが, ここに報告するのは, そのらちの 1 つで, 現在改造作 業中のところもあるが, ワンボード型のマイコンが中 心になっているシステムである。つまり，よく見られ るパソコンのよらな “完成品” の形をしたマイコンで はなく, 1 枚の板の上に ICを配列しただけのもさ出し の形のマイコンを使用しているシステムである。この システムをこの報告でとり挙げたのは，その用途も含 めてこの特集に多様性を持たせることになるのではな

* 立教大学文学部 (Faculty of Literature, Rikkyo University)

この研究には昭和 57 年度文部省科学研究費補助 金 (一般研究 C, 課題番号 57510057) と東大大型 計算機センターが用いられた。
いかと考えたからである。

\section{1. システムの特徴}

このシステムは, 大型計算機と TSS 結合された形 になっている動物・生理実験の制御・計測システムで ある、このシステムに組込まれているマイコンは, ワ ンボード型のマイコン 3 個である. 1 個 13 万円ほどの 低価格でメモリが $152 \mathrm{~K}$ バイトもついた日立の H680TR という 16 ビットのワンボードのマイコンが 2 個と, 数万円の Intel の 8 ビットのワンボード・マイ コン SDK-85 が 1 個である.これらのマイコンは互に 結合されているが, 動物・生理の実験器機, プリン ター・タイプライターや X-Y プロッタなどの端末, 拉 よび大型計算機との TSS 結合用の音響カプラーとも 結合している。したがって，このシステムは，一方で は動物・生理実験の制御・計測に用いられ，他方では 大型計算機のオンライン利用にも用いられる.

最近では，有名ブランドの OSを備え使い易すそう 
に見えるパソコンが多く氾濫している．このような時 期に当研究室でワンボード・マイコンを実用している 理由やメリットは何かを考えてみる.そのひとつには, 当初この動物・生理実験システムを作った時にワン ボード・マイコンを採用し，その後このシステムを改 良・拡張してきているといら流れがあり, システム作 りには多大の労力を要するといらことがある.しかし， より主要な理由としては, 低経費で資源の有効利用, 大 型計算機網の共同利用, 拈よびシステムの最適化の発 想がある.この考えは, このシステム設計の当初から あり，現在にも受け継がれている。

ミリ秒のオーダーの処理を要するチャンネルや $\mu$ 秒オーダーの A/D 変換のチャンネルなどをいくつか 含さ複雑な実験を精密に実施するには，コンピュー ターが助けになる。これから記す当研究室のシステム が行ら動物・生理心理学の実験もこの部類に属する.コ ンピューターをこのような実験に使らには, オンライ ン・リアルタイム利用による即応処理を要し, 独占使 用となる。大型計算機は 1 実験に独占使用するには適 さず, 比較的安価なマイコンが適している.マイコンに も多種類があり, 汎用的 OS も完備しミニコンに近い “完成品”から，シンプルなワンボードのマイコンまで ある。“完成品”は使いやすそうに思えるが，使いやす さは, 当然のことながら, 使用者側の条件と使用目的・ 内容によって決まるものである。“完成品”が暗に念頭 に置いている使用者と使用法には適していて使い易い であろらが，それ以外のためにはそらではない. 単に 数值計算をさせるだけの使用であっても，演算回数の 多い数值計算, 収束計算, シミュレーションなどの場 合には，現状のマイコンではその計算に数日を要する こともあり得る。その計算にェラーを伴う場合はなお 手間がかかる.このよらな作業には使い易くなく, スー パーコンピューターの方が使い易い. 実験の制御・計 測に使用するには，マイコンと実験器機とを接続しな ければならない、“完成品”の中には, 外部器機との接 続用の端子がついていないものも多い:それでもシス テムが公開されていれば，分解してハードウェアの工 作をして実験器機と接続できるが，“完成品”であるだ けにハードとソフトの両面で既成部分からの影響と既 成部分への影響が心配になり，結局他の人が作ったシ ステムを全部掌握しなければならず使いにくい. シス テムが公開されていなければ括手上げである。外部器 機との接続用の端子が本体についているか，または挔 張用ユニットとしてついている場合には, 外部器機と
接続できる.この場合にも 2 つのケースがある。その 1 つは，接続用端子はハード的についてはいるが，その 利用に関してはシステムのソフトは何もなく, マニュ アルも簡単なものだけの場合である。この種のマイコ ンの端子を利用するには，まずこの機種についての市 販の詳しい書を求めて(システムが公開されていて, し かもこのような書が出ているものについてのみ可能), システムの構成を理解し, 既成のシステムソフトウェ アの外で使うことになる。つまり，これらの端子，た とえば割込み用端子の利用可能な高級言語がシステム ソフトになく，アセンブラーもシステムソフトにない ために，他の “一般向け” のシステムソフトは完備し ているのにそれらを使らことなく，機械語になった実 験用ソフトをユーザーが作りそれをマイコンに直接入 れることによって外部器機との接続端子を利用するこ とになる。もう 1 つのケースは, 外部器機との接続端 子がついていて，しかもシステムのソフトウェアでそ の利用についても面倒をみている機種である。一応完 備していてよいが，このクラスの機種になると最小構 成でも価格が 100 万円を超えるようであり，しかもシ ステム的に無駄が多かったり足りなかったりする．完 備しているので，実験の制御・計測に直接関係のない こともシステムプログラムがいろいろと面倒をみるよ らになっている.このため, せっかくのメモリのらち のかなりの部分をシステムが占めてしまうし， システ ムの中で実験ソフトのユーザプログラムが動くので実 験姏理以外のことも行っているので実験処理の動作が 遅くなる. 完備している端子にしても，“一般的水準” を念頭に执いて設計されているので足りないこともあ る.たとえば, 外部割込み用の端子が $3 〜 4$ チャンネル 備わっているのもあるようだが，当研究室の実験には 少くとも8〜10 チャンネル必要である. 完成したシス テムで不足を感じた場合にそれを変更するのはむずか しい.

メンテナンスの費用も含めての低経費, マイコンの 長所を生かした贅肉のない小回りのきく，実験の条件 にフィットした，知り尽されたシステムといら発想か ら，ワンボードのマイコンが使われている。ワンボー ドのマイコンは, ハードとソフトの両方が公開されて いてシンプルなので, 全体の把握が比較的容易である. よく把握した上で, 必要に応じて安価な ICを追加し たりメモリ・ボードを追加したりしていけばよい。た とえば外部割込用の端子が不足であれば，必要な数だ け割込コントロール用のICなどを付加すればよい. 
使用条件に適合したシステムソフトを作って使う、数 キロバイトもあれば, かなり便利なシステムソフトが できる。

ただ単に, 外部実験器機との接続使用がハードとソ フトの面でしやすく実験の制御・計測に向いていると いらことだけでマイコンの選択を考学るのは不十分で あろら.その他の機能についても配慮すべきである.た と觉ば，実験実施に先立ってのその実験用ソフトウェ アの作成, 実験で得られたデーターの保存と分析, 分 析のためのプログラムの準備, 分析結果の図表化, シ ミュレーションによるモデルの検討, 学術文献情報の 利用, 論文の作成などのための機能はどうであろうか. "完成品"のマイコンは, これらの機能のらちのいくつ かを有しているが，ワンボードのマイコンには汪とん ぞない，そこで，当研究室のシステムでは，大型計算 機をオンライン結合で利用することで，これらの機能 を補い強化している.実験器機との接続とその利用, タ イプライターなどの端末との接続とその利用のほか に, 音響カプラーを通しての大型計算機の TSS オン ライン利用が含まれている。当システムを使用してい ると, 小回りのきくヴァーチャル (仮想) 大型計算機 を専用に組込んだシステムを使用しているような感じ になる.大型計算機の豊富な機能や器機が利用できる. 現状では, “完成品”のマイコンでもこれほどの機能や 器機は備えていない。つまり, 当システムは, 現時点 でのマイコンの長所と大型計算機の長所とを取り込ん だシステムといえそうである。もちろん，心理学の実 験といっても種々あるので, それ汪どの即応を要しな いもの, 外部実験器機との接続を注とんど要しないも のもあるので, 実験の種類によっても適するマイコン の種類は異なることは付言すべきである.とにかく, 、 イコンには，マイコンに “適した” 比較的簡単な部分 だけを分担させ，その他は大型計算機にさせられるよ らな統合されたシステムにして拉くと, システムの性 能アップにも都合がよい.コンピュータ関係の技術の 進歩は著しい。大型計算機もさらに性能アップした新 機種に入れかえられていく.サービス内容もょくなる. 学術文献データ・ベースなどのサービスの大型計算機 システムなども改善されてくる。このようなときにも, 当システムにはほとんど変更なしに, これらの性能 アップした大型機の機能をシステムに組込んだ形で利 用できる。マイコンの側の性能アップにも比較的低価 格で対応できる. 当システムのマイコンも, 当初は 8 ビットのワンボード型マイコン SDK-85 のみであっ
たが, その後メモリ量, 命令の種類, 演算対象のデー タ長, 処理速度などの点で性能の向上した 16 ビットの ワンボード型のマイコンが比較的低価格で出現したの で, これをシステムに組込みシステムの性能を飛躍的 に向上させることになった。

\section{2. システムの構成}

システム構成の概略は図 1 に示されている. システ ムの中心的位置にワンボードマイコン SDK-85があ る. このマイコンは, パラレル $\mathrm{I} / \mathrm{O}$, シリアル $\mathrm{I} / \mathrm{O}$, お。 よび割込みチャネルを介して, 他の 2 つのワンボード マイコン H680TR と結合している. 大型計算機とは, 音響カプラーと公衆回線を通して接続される. SDK85 は, タイプライター, 紙テープ装置, $\mathrm{X}-\mathrm{Y}$ プロッ ター, ディスプレイなどの入出力器機, および実験器 機やクロックとも接続している.SDK-85 は, 実験の制 御・計測のほかに, システムのこれらの各部分の統合 的利用のための働きもしている。この働きは, ROM に 入ったシステムプログラムによっている。このような

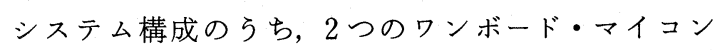
$\mathrm{H} 680 \mathrm{TR}$ とその関連部分以外の部分は, 基本的には旧 システムと同じであり，旧システムについては既に報 告しているので (石井 (1979), 石井 (1980)), ここで は主として H680TR とその関連部分について記す。

一方のワンボード・マイコン H680TRは, 動物・生 理実験に打ける動物の行動パターンの計測のための画 像解析に用いられる。もら一つの H680TR は, 同じく 動物・生理実験に打けるその他の計測, 特に, 多チャ ンネル (微小電極) から 10 ミリ秒ごとの神経パルス数 の比較的長時間に及ぶ計測に用いられたり, 微小電極 からの神経パルス活動の波形の連続のアナグロ情報を 比較的長時間にわたって $\mathrm{A} / \mathrm{D}$ 変換により計測し記憶 し D/A 変換で再現するのに用いられる.

ワンボード・マイコン H680TR の CPUは 16 ビッ トタイプの 68000 である. バスがマルチ化されていな いこともあって CPU の足は 64 本もある。マルチ化さ れていないのでハード的に扱いやすい. 16 本のデータ 線と $\mathrm{A}_{0} \sim \mathrm{A}_{23}$ のアドレス線とが分離されている.メモ リは 16 メガバイトまで設定できるが, 購入時には 128 $\mathrm{K}$ バイトの $\mathrm{RAM}$ と $24 \mathrm{~K}$ バイトの $\mathrm{ROM}$ (モニタ，ア センブラー，テキストェディタ）が実装されている. $\mathrm{ROM}$ は差し換えることで $32 \mathrm{~K}$ バイトになる.さらに 必要に応じて 40000 番地から FFFFFF 番地までメモ リの拡張が可能である。このように大量のメモリを有 


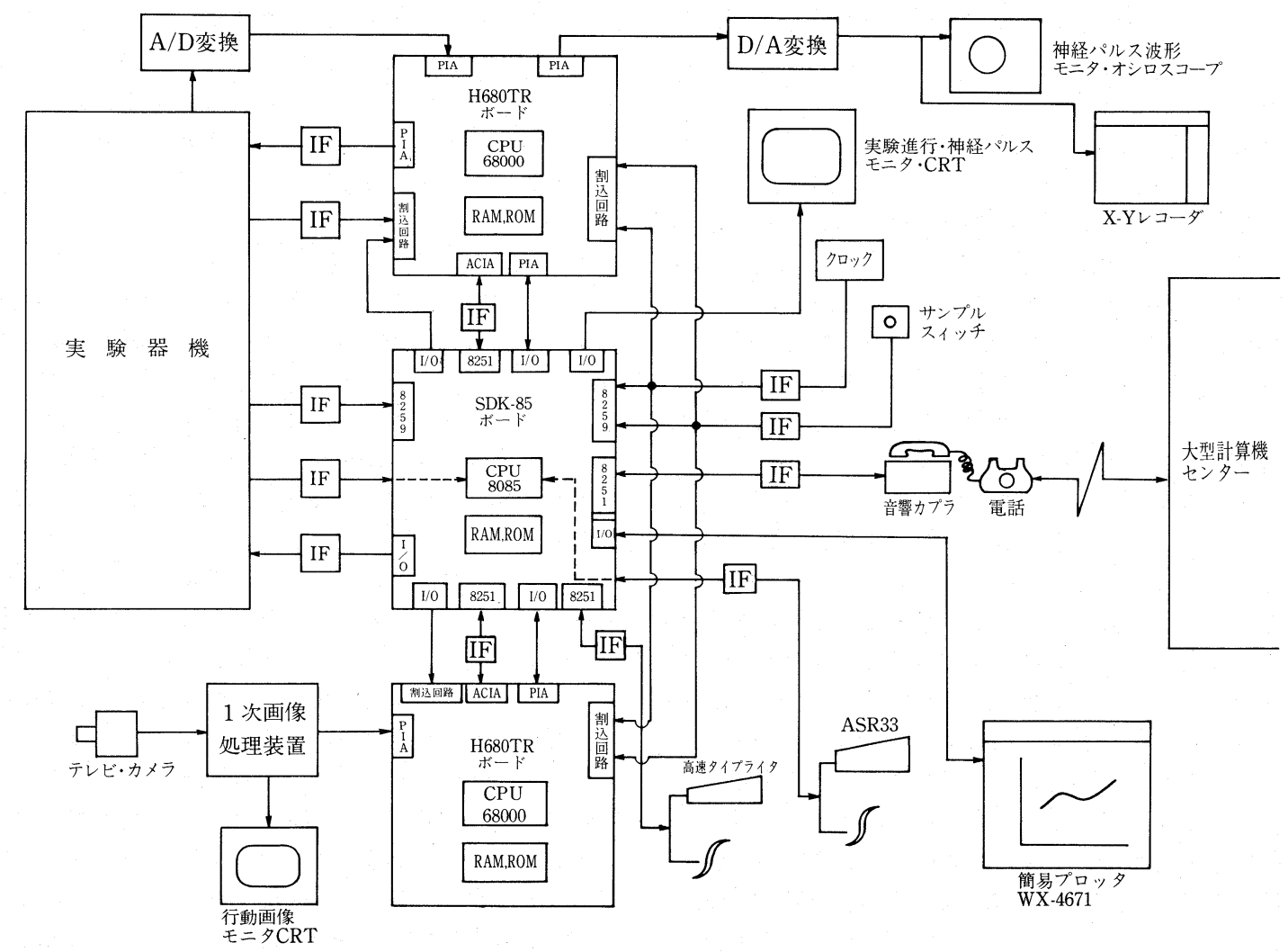

図 1. システムの概略

寸るので, 10 ミリ秒間隔での神経パルスの計測などの 際に感じていた 1 次データ用のメモリ不足が改善され る. $128 \mathrm{~K}$ バイトでも 10 年前の中型コンピュータや現 在のミニコンに匹敵する.CPUの処理対象のデータタ イプは, 標準は 16 ビットで 1 ワードであるが, 32 ビッ トのロングワード, 8 ビット, 1 ビットも扱光る。 た えばMOVE 命令では，このままでは 16 ビットを対象 とするが，MOVE. L とするとロングワードを対象に し, MOVE. B とすると 8 ビットを対象にする. 16 ビッ ト長, 32 ビット長の処理が 1 命令でできるので, 実験 の計測・制御のプログラムの作成には助けになる。旧 システムは 8 ビット・マイコン SDK-85 だけであった ので，同じことをさせるのにいくつかの命令を使って プログラミングをしなければならなかった．動物・生 理実験の計測・制御に揖いて 8 ビット長より長い数值 を扱うことも多いが，当システムは，そのプログラム 作成の時間を短縮させ労力も軽減させる．それに伴っ てプログラミングの誤りを減少させ，プログラムの実
行時間を短縮させ, 処理速度を速め即時処理の精度を 高める.CPU のもつレジスタも豊富である. 32 ビット 長のデータ・レジスタ 8 個・32 ビット長のアドレス・ レジスタ 7 個, 32 ビット長のスタック・ポインタ 2 個, 32 ビット長のプログラム・カウンタ 1 個, 16 ビット長 のステータス・レジスタ 1 個を有する， 32 ビット・マ シン指向のマイコンと言光る。アドレス・モードも豊 富で, 14 種類ある。レジスタを使っての，アドレス・ レジスタ間接，インデックス付アドレス・レジスタ間 接, デイスプレースメント付アドレス・レジスタ間接, インデックス付プログラム・カウンタ相対形成などの モードもある。このようなアドレス・モードの豊富と レジスタの豊富さ，打よびレジスタを用いてのアドレ ス計算などが, 実験用プログラムの作成の助けになる。 たと壳ば，アセンブリ言語による画像処理プログラム の 2 次元データの扱いや, データをくり返し得るルー プでの扱いなどの場合である.

使い易い命令が豊富なこともプログラミングを助け 
る. 68000 には乗算命令や除算命令がある.演算結果が 32 ビット長まで求められる符号付き 2 進乗算命令 MULS, 32 ビット長の被除数を扱える符号付き 2 進除 算命令 DIVS，同様の符号なし乗算命令 MULU と符 号なし除算命令 DIVUがあり，1 命令で乗算または除 算が行える. 10 進加算命令の $\mathrm{ABCD}$ 扎よび 10 進減算 命令の SBCD もある. 減算付き条件分岐命令 DBcc は，オペランドに示されたデータ・レジスタの内容を 1 減じ, 16 種の条件のうち指定された 1 つの条件 cc が 満たされているか, または, オペランドに示されたデー タ・レジスタの内容がー1になっているかによって分 岐する。ある条件が満たされるまで，または，ある一 定の回数になるまで，くり返しをするループのプログ ラム作成に便利である。クリア命令 CLR は，オペラン ドの内容を 0 にする。実効アドレス・ロード命令 LEA は，アドレスの值をアドレス・レジスタに入れる。ア ドレスの值の操作に使える. 符号拡張命令 EXTは, 語 長の異なる数值間の演算に便利である. LINK 命令は, オペランドに与えられたレジスタの内容をスタックに 退避させ，スタック・ポインタをその分だけ減じ，そ の減じた結果のスタック・ポインタ值をレジスタに与 えて知らせてくれ，さらにオペランドに与えた数值 $\mathrm{d}$ だけスタック・ポインタの值を減じてくれる.したがっ て，サブルーチン内で， $\mathrm{d}$ バイトだけ余分にスタック 領域が退避用またはサブルーチン用に使える。 UNLINK 命令は, LINK 命令の逆操作を行ない, ス タックをもどすことをする.プレ・ディクレメント・ アドレスレジスタ間接拈よびポスト・インクレメン ト・アドレスレジスタ間接のアドレス形式があるので, 連続したメモリ番地の内容を順に処理していくのに便 利である.たと竞ば, MOVE (A 1) +, D 1 は, ポスト・ インクレメント・アドレスレジスタ間接形式を用いた 例であるが，アドレスレジスタ A 1 の内容が示す番地 の内容 (1 語長) をデータレジスタ D 1 へ入れ, その後 A 1 の内容を 2 だけ増加させる. したがって, 次にこの 命令を実行するときには， 2 番地先のアドレスの内容 を自動的に処理することになる.

CPU 68000 の処理モードにはスーパーバイザー・ モードとューザ・モードがあり，ステータス・レジス タの S フラグに示される. スーパーバイザー・モード でプログラム参照であるかデータ参照であるか, ユー ザ・モードでプログラム参照であるかデータ参照であ るかを示すために, 68000 には 3 本の端子 $\mathrm{FC}_{0}, \quad \mathrm{FC}_{1}$, $\mathrm{FC}_{2}$ が出ている。これとアドレスバスとを組合わせる
ことにより，メモリ保護もできる.ユーザ・モードで は使えない命令もある. 特権命令であり，ユーザ・モー ドでそれを使うと特権命令違反の例外が発生するよう になっていて，安全策がとられている.

68000 の例外処理の種類も豊富で数も多い. 例外処 理べクタによって例外処理要求を区別するが，そのべ クタ番号は 0〜255の 256 個が可能である. システム用 に設定されている例外処理とユーザが設定する例外処 理とがある、システム用の例外処理のなかには，内部 割込に属するものもいくつかあり，プログラム作成の 助けになる。 ゼロディバイドによる例外処理, 算術演 算のオーバーフーローに関連する TRAPV 例外処理, ユーザ・プログラムが実行中に参照するデータ領域の 境界越えに関する $\mathrm{CHK}$ 例外処理, 特権命令違反の例 外処理，アドレス・エラーによる例外処理などがある. 特権命令違反の例外は特権命令をユーザ・モードで実 行しようとすると発生する。アドレス・エラーによる 例外は，ワード長またはロング・ワード長のオペラン トの番地が奇数で始まっているとき，または，命令が 奇数番地からのメモリにあるとき，それらへのアクセ スによって発生する。TRAP 命令による例外は, TRAP 命令を実行することによって発生する.TRAP 命令は，オペランドとして\# 0 から\#15 をでの 16 種類 のイメディエート・データが可能であり, それに対応 して 16 種類の TRAP 命令例外がある. H680TR の乇 ニタでは, スナップショット・ダンプ, タイプライタ からメモリへの入力, メモリからタイプライタへの出 力, 紙テープリーダからメモリへの入力, メモリから 紙テープパンチャへの出力, 2 進数から 16 進教への変 換, 2 進数から 10 進数への変換, 16 進数から 2 進数へ の変換, 10 進数から 2 進数への変換, モニタへの分岐 などの機能を，TRAP 命令例外処理に割り当ててい る.この例外処理ルーチンは，モニタの中にあってモ ニタが使っているが，ユーザも使光るよらになってい る. 不当命令の例外, バス・エラーの例外, トレース の例外，リセットの例外などもある．不当命令の例外 は,フェッチされたオペュードのビットパターンがど の命令のビットパターンとも一致しないときに発生す る.バス・エラーの例外は，メモリの配置されていな い番地へアクセスしたとき，または，書き込むべきで ないメモリへ書き込み命令を出したときに発生する. トレースの例外は, ステータスレジスタのビット 15 が セットされているとき 1 命令の実行終了ごとに発生す る.リセットの例外は，リセットスイッチを押すこと 
によって発生する。これらの豊富な例外は, 実験用プ ログラムの誤りの発見と除去, 誤ったプログラムの効 果の抑制, プログラムの作成の助力, システムの初期 化などに使われる。これらの外に，ニーザが設定でき る外部からの割込みの例外があり，新システムでは実 験器機やタイマなどからの割込み処理に使用してい る.

H680TR には, $8 \mathrm{~K}$ バイトのモニタと, $16 \mathrm{~K}$ バイト のアセンブラとテキスト・エディタがついている，当 システムはこれらも利用する形にした。モニタの利用 には, モニタのコマンドの利用, モニタからのメッセー ジの利用，モニタのルーチンの一部をTRAP 命令の 形でプログラムに取り入れての利用などがある。モ= タ・コマンドには 16 種類がある。 アセンブラを呼出す AS コマンド，ブレークポイントの設定や設定された ブレークポイントのタイプライタへの表示をさせる BR コマンド, レジスタの内容をタイプライタに表示 させる $\mathrm{DF}$ コマンド，任意の番地からプログラムの実 行を開始させる GO コマンド，メモリ内のオブジェク ト・プログラムを紙テープヘ出力させる PU コマンド, アセンブラによって作られたメモリ内または紙テープ 上にあるオブジェクト・プログラムを指定されたメモ リヘロードさせるLO コマンド，メモリ内容をタイプ ライタへ表示させる MD コマンド，メモリ内容の参照 と変更をさせる MM コマンド, 設定されているブレ一 クポイントを解除させる NOBR コマンド，レジスタ 内容の表示用指定を解除させるNODF コマンド， ア ドレスのオフセットを設定する OF コマンド，レジス タの内容の参照と変更をさせる $\mathrm{RM}$ コマンド, 1 命令 実行ごとにレジスタの内容をタイプライタに表示させ て指定した命令数だけトレースをさせる TR ママン

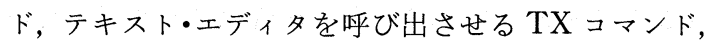
アセンブラで作られてメモリ上または紙テープ上にあ るオブジェクトプログラムとロードされているオブ ジェクトプログラムとの一致を調べさせるVEュマン ドなどである。これらのコマンドは, 当システムのソ
フトゥェアや実験用プログラムの作成, 試用, 実行, 保 存に使われる. H680TRのテキスト・エディタは 12 種 のサブコマンドを持っている．紙テープからテキスト を入力する Aサブコマンド，紙テープヘテキストを出

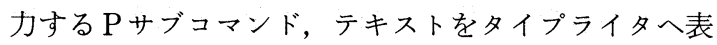
示する Tサブコマンド，ポインタをバッファの先頭へ 移動するBサブコマンド，ポインタをバッファ内のテ キストの最後へ移動するZサブコマンド，ポインタを 指定した行だけ移動させるLサブコマンド，文字列を テキストの中からさがしポインタをその文字列のある 行の先頭へ移動する $\mathrm{S}$ サブコマンド，テキストを挿入 するI サブコマンド，文字列を入れかえるCサブコマ ンド, テキストを行単位で削除する Kサブコマンド, コ マンド列のくり返しを行ならNサブコマンド，テキス

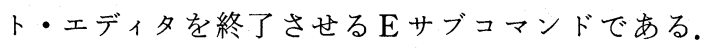
H680TR のアセンブラには, サブコマンド P 1, P 2, P 3, PM, PT, QU がある.P 1, P 2, P 3 は，紙テープ上 のアセンブリ言語のソースプログラムを 3 パス方式で アセンブルする場合の, それぞれパス 1 , パス 2 , パス 3 実行のサブコマンドである。 PM は，テキスト・エ ディタで作成したメモリ上にあるソースプログラムを 一挙にアセンブルするサブコマンドである.PT は, 紙 テープ上にあるソースプログラムを一挙にアセンブル するためのサブコマンドである.QU は, アセンブラを 終了させるサブコマンドである. H680TR の命令セッ ト，モニタ，テキスト・エディタ，アセンブラなどの 詳細については, 日立製作所の文献を参照されたい.当 システムでも, これらのモニタ, アセンブラ, テキス ト・エディタを使うようにしてある。システムプログ ラムや実験実施用プログラムのデバグ, 試用, 実行に モニタは便利である。アアセンブラやテキスト・エディ 夕も, 比較的簡単なプログラムのときは, 手軽に使党 て便利である。しかし，やや大きなプログラムのとき は, 東大大型計算機とオンライン TSS で, その OSや クロスンフトウェアを利用した方がよい。より使い易 いェディタや 68000 用クロスソフトウェアもある（山

表 1. H680TR ワンボード・マイコンのメモリ・マップ

\begin{tabular}{|c|c|c|c|c|c|c|c|c|}
\hline $\begin{array}{llllll}0 & 0 & 0 & 0 & 0 & 0 \\
0 & 0 & 0 & 3 & & \\
0 & 0 & 0 & 3 & F\end{array}$ & $\begin{array}{llllll}0 & 0 & 0 & 4 & 0 & 0 \\
0 & 1 & \mathrm{~F} F & \mathrm{~F} & \mathrm{~F} \\
\end{array}$ & $\begin{array}{llllll}0 & 2 & 0 & 0 & 0 & 0 \\
0 & 2 & 1 & 1 & F & F\end{array}$ & $\begin{array}{l}022000 \\
023 \mathrm{FFF}\end{array}$ & $\begin{array}{llllll}0 & 24 & 4 & 0 & 0 & 0 \\
0 & 2 & 7 & \mathrm{~F} & \mathrm{~F} & \mathrm{~F}\end{array}$ & $\begin{array}{lllll}0 & 28 & 8 & 0 & 0 \\
0 & 3 & \mathrm{FE} & \mathrm{F} & \mathrm{F}\end{array}$ & $\begin{array}{l}03 \mathrm{FF} 00 \\
03 \mathrm{FF} 3 \mathrm{~F}\end{array}$ & $\begin{array}{l}03 \mathrm{FF} 40 \\
03 \mathrm{FFFF}\end{array}$ & $\begin{array}{l}040000 \\
F F F F F\end{array}$ \\
\hline $\begin{array}{c}\mathrm{RAM} \\
(1 \mathrm{~KB}) \\
\end{array}$ & $\begin{array}{c}\text { RAM } \\
(127 \mathrm{~KB})\end{array}$ & $\begin{array}{c}\text { EPROM } \\
(8 \mathrm{~KB})\end{array}$ & $\begin{array}{c}\text { EPROM } \\
(8 \mathrm{~KB})\end{array}$ & $\begin{array}{l}\text { EPROM } \\
(16 \mathrm{~KB}) \\
\end{array}$ & \multirow{2}{*}{$\begin{array}{l}- \\
-\end{array}$} & \multirow[b]{2}{*}{$\mathrm{I} / \mathrm{O}$} & \multirow[t]{2}{*}{-} & \multirow{2}{*}{$\begin{array}{l}\mathrm{I} / \mathrm{O} \text { とx乇 } \\
\text { リの払張用領 } \\
\text { 域 }\end{array}$} \\
\hline $\begin{array}{l}\text { 例外処理ベク } \\
\text { タ・アドレス }\end{array}$ & $\begin{array}{l}\text { 実験用プログ } \\
\text { ラムとデータ } \\
\text { など }\end{array}$ & $モ=タ$ & $\begin{array}{l}\text { システム・プ } \\
\text { ログラム }\end{array}$ & $\begin{array}{l}\text { アセンブラと } \\
\text { テキストエ } \\
\text { ディタ }\end{array}$ & & & & \\
\hline
\end{tabular}


本 (1982)). 大容量ファイルもある。

当システムに組込まれた 16 ビット型のワンボー ド・マイコンH680TRのメモリ・マップを表 1 に示す. 例外処理ベクタ・アドレスの領域は, 前述のシステム 例外処理, および実験器機や他のワンボードからの割 込処理のためのジャンプ・テーブルである. 256 種まで 設定可能である。000400 01 FFFF は, 実験用プログ ラム, 実験データ, システム・パラメータ，モニタ・ パラメータの領域である. エディタやアセンブラを使 うときには，一部がワーク・エリアにもなる。020000 番地からの $8 \mathrm{~K}$ バイトのモニタは前述のモニタであ る. 022000 番地から $8 \mathrm{~K}$ バイトのシステムプログラム は, SDK-85 のワンボード, 周辺器機拉よび大型計算機 と連携して当システムを機能させるための当システム のプログラムの部分である. システムプログラムの他 の部分は，もら一方の H680TRのワンボード拈よび SDK-85のワンボード内にある。つまり 3 ののワン ボード上に分散していて互に連携して機能する。 024000 番地からの $16 \mathrm{~K}$ バイトには前述のアセンブラ とテキスト・エディタが入っている. $03 \mathrm{FF} 00$ 番地から $03 \mathrm{FF} 3 \mathrm{~F}$ 番地玉では, メモリマップト I/O である. 040000 番地から FFFFFF 番地までは, メモリまたは $\mathrm{I} / \mathrm{O}$ の拡張可能な領域である.

H680TRのワンボードには, 実験器機, SDK-85 ボード, クロック, サンプル・スイッチ, A/D 変換, D/ $\mathrm{A}$ 変換, 1 次画像処理装置などが接続される。これらの 接続に, H680TR 側では, HD 46821 という PIA の IC や HD 46850 という ACIA の IC も使われている. HD 46821 の IC 1 個につき, 8 ビット並列の入出力用ポー トが 2 ポートと, 割込要求端子 4 本がある.この ICを 2 個並列に用いることによって，16 ビット並列の入出 カポートが 2 個できる.アンプから出てきた神経パル ス波形のアナログ信号を $\mathrm{A} / \mathrm{D}$ 変換にかけ，その出力 をクロック割込に同期して並列入力出力ポートからメ モリへ取り込んでいく。メモリに貯蔵された波形デー 夕は, 別の並列入出力ポートから出力され $\mathrm{D} / \mathrm{A}$ 変換 を通してモニタ・オシロスコープやX-Yレコーダへ 与兄られる。メモリ内波形データは, パルス巾度数分 布やパルス振巾度数分布などの諸パルス分析処理にか けられたり，混入している不用波の削除などの波形整 形を受けた後にモニタ出力されたり分析されたりるす る. 並列入出力ポートは, 1 次画像処理装置とも接続さ れている。テレビ・カメラから 1 次画像処理装置へ 1 ドット 16 段階の濃淡の 1 画面分の情報 $(256 \times 256)$ を
$1 / 60$ 秒ごとに取り込み 1 次画像処理装置内のメモリ に保持される。これにその都度 H680TR が並列入出力 ポートを介して高次の画像処理をしてその時の行動を 判定する.その時その時の判定された行動は, 行動パ ターン名のデータとして貯蔵される。このデータは, 後 に神経パルスデータと対応がとられ分析される. H680TR の並列入出力ポートは, SDK-85 のワンボー ドとの連絡にも使われる. H680TR で得られたデータ の転送, 実験の進行状況の情報の授受, システムのス テータス情報の授受などに使われる。

ACIA の HD 46850 は直列入出力用ポートであり, SDK-85 ボードとの接続に用いられる。 300 ボーから 9600 ボーまでのレベルの速度のうちの1つで直列入 出力が行なわれる。この ACIA は, H680TRの入出力 用としての ASR タイプのコンソールを接続するため に始めからついているものであるが, 当システムでは, これを SDK-85 ボード上の新設の RS- $232 \mathrm{C} レ$ レ゙直 列入出力部々接続している。これを介して H680TR と SDK-85 との情報の授受も行われる。これは, SDK-85 ボードを介しての H680TRボードと高速タイプライ タ 0262 との情報の授受 (入出力) にも使用される。こ の ACIA は, SDK-85ボードを介しての H680TR ボードと大型計算機との情報の授受にも使われる。 SDK-85 ボードは，柄は小さいが，2つの H680TR ボード, 周辺器機, 大型計算機, おょび実験器機など を仲介・統合する中心的位置にあることになる．

H680TR ボードに対する外部割込には，外部割込制 御回路が使われている。この回路には，実験器機から の入力信号, クロックからの入力, サンプル・スイッ チからの信号，拉よびボード間の同期信号が接続され る。この回路は，諸入力信号に応じて割込及に関する コントロール信号の処理とベクタ番号の発生とを行な ら.この番号を CPU が読み込み, その番号の例外処理 ジャンプ・テーブル内のアドレスに処理がらつり, 割 込及処理がなされる。つまり, 割込入力信号の種類に 応じた処理がされることとになる。

SDK-85 ボード部分については，前述のように既に 報告した旧システム（16 ビット・マイコンを用いない， 8 ビットマイコンSDK-85を中心にしたシステム）と 基本的には同じところも多いが，この新システムの中 心的位置を占めているので, 当システム全体の把握の ために簡単に記す。CPU は Intel の 8085 である.CPU に割込用信号入力のピンが 5 本ついている。このうち の 4 本は，信号入力によってそれぞれ特定番地へ分岐 
をひき起す。残りの 1 本は, 割込みコントローラIC の 8259 へ接続することで, 最大 64 個の割込及処理が可 能となる。実験制御やシステム制御に便利である。 SDK-85 のメモリは, 購入時についている簡単なモニ タの入った ROM (2 KB), システムプログラムを入れ た EPROM (6 KB), RAM(約 $33 \mathrm{~KB}$ ), 簡易 EPROM ライターである. SDK-85 と, 前記の H680TRの ACIA との接続, 高速タイプライタとの接続, および大 型計算機との接続のための音響カプラとの接続には, それぞれ別個に直並列変換 IC の 8251 と電圧レベル 変換 IC の MC 1488 と 1489 が用いられている。実験器 機との並列結合, モニタ CRTやX-Y プロッタなどの 周辺器機との並列結合, 括よび前記の H680TRの PIA との並列結合には, 並列 I/O を含む IC の 8155 , 8255, 8355, 8755 が用いられている. Intel の 8 ビット マシンは，このように周辺用 IC が豊富なのでハード ウェア面での利用のし易さに扮いてすぐれている。こ の点では 68 系マシンは劣っているように思える.

以上は当システムの構成の概略である。このシステ ムの機能や使われ方について以下に記す。

\section{3. システムの機能と用途}

既に述べたように，このシステムは，動物・生理実 験の制御・計測および大型計算機との TSS オンライ ン結合利用に使われる。いずれの場合も，SDK-85 の ボードがシステムの中心的位置を占め，よろずや的に 種々の働きと統合の働きをしている. H680TR のボー ドは, 動物・生理実験に打ける画像処理による行動パ ターンの計測, 神経パルスの波形の記憶・処理, お上 び神経パルス数のカウントなどの，特定の処理とその 関連事項に主に使われる。つまり, H680TRは, 全処 理のらちで，多くのメモリと多くの処理時間を要する まとまった一部の処理のみを専ら分担する. SDK-85 のボードは，その他の処理を分担し，さらに全体を統 合する働さの多くの部分も受け持っている.

このシステムを用いての動物・生理実験は, 主とし てラットを被験体としての動因間交互作用に関するも のである.Warden 型の障害箱の実験, $\mathrm{Y}$ 迷路での 2 動 因の弁別，スキナー箱での 2 動因の弁別，これら 2 動 因弁別時に抢ける第 3 の動因導入の効果, さらに動因 強度の弁別などの実験, これらの事態に拉ける行動の 計測と脳内関連諸部位の神経パルス活動の計測などが なされる. 脳内の複数部位からの同時並行しての神経 パルスのディジタル情報入力, アナログ波形入力, 左
右のバー押し情報の入力, 選択点や通過点情報入力, 波 形処理のためのマイクロ秒，パルス・カウントのため のミリ秒,バー押し間隔のための $1 / 10$ 秒または秒など のオーダの時間信号の入力, 処理の同期のための信号 の入出力, サンプル指示信号入力, 刺激の出力, 強化 のための信号の出力, モニタ CRT や経過記録のため の出力など, 実験実施に当ってのこれらの情報の適切 な処理のために，当システムが使われる。

当システムをこのような実験に使うためには，その ようにマイコンを動かすプログラムが必要である。実 験ソフトの作成であるが，この作成のためにも当シス テムが使われる. CS モードで行なわれる。当システム は, 各モード別に動く.タイプライタから入力された モードの設定. 変更によってマイコン内にモードフラ グのビットがセットされ, それに応じてシステムプロ グラムが分岐して動く. CS モードは大型計算機と SDK-85 ボードとが音響カプラーを介してオンライン 結合してTSS で動くモードである. この場合, 当シス テムの SDK-85 ボードとタイプライターとはインテ リジェント端末化したことになり，H680TRボードと は独立に動くので, H680TR ボードに別の作業, たと えば実験の制御などを並行してさせておくことも可能 である.CS モードで大型計算機の便利で豊富な OSや システムソフトを使って実験プログラムが作られる. まず，エディタを呼び出してそれを使って実験用プロ グラムをタイプライターから入れ, 必要に応じて編集 し, 大型計算機のファイルに保存する.SDK- 85 ボード 用の実験プログラムは, 8085 のアセンブリ言語または 高級言語の PL/M で書かれており，H680TRボード 用の実験プログラムは, 68000 のアセンブリ言語で書 かれたものである。このようにして, 実験用ソースプ ログラムができると，次にこれをアセンブルまたはコ ンパイルしてマイコンの機械語に変換しなければなら ない，東大大型計算機センターには，このよらな変換 をしてくれる便利なクロスアセンブラーやクロスコン パイラーがあるので，それを使って変換を行なら（詳 細については, 池田・山本(1979), McCracken (1978), 石田（1980）, 石田・小野 (1978), 山本 (1982)を参 照のこと).この変換によって得られたマイコン用機械 語のオブジェクトプログラムは, コマンドの入れ方に よって, 直接当システム側へ送出することも, 大型計 算機のファイルに保存することもできる，アセンブル 時またはコンパイル時にプログラムの誤りが指適され ればエディタに戻ってンースプログラムを修正し, 再 
び変換を試みる。でき上ったオブジェクトプログラム は, 通常は大型計算機のファイルに保存し, 必要に応 じて当システムへ送出して使う。変換時には指摘され ずに実行時にはじめて見つかるプログラムエラーもあ る.この種の䛊りを本番の実行前に発見し，実験用プ ログラムが期待通りに動くかどらかを点検することも 必要であるが，マイコンプログラムの実行を大型計算 機上で模倣してくれるクロスシミュレータが東大大型 計算機にはあるので，これを使って点検ができる。こ れを使らと, マイコンプログラムの 1 ステップずつま たは指定したポイントまでを “実行”させ，その都度 直後のレジスタやメモリや実行番地などの状況を知る ことができるので，プログラムが予定通り動くかどう かを追っていくことができる。

でき上って大型計算機のファイルに保存された実験 用オブジェクトプログラムは，実験時に当システムの マイコン内ヘオンラインで直接送り込まれて使用され る.オブジェクトが SDK-85 ボード用のものであれ ば，当システムは CS モードで動くことで SDK-85 ボードのメモリの該当番地からにオブジェクトが入れ られる.H680TR ボード用のものであれば, CSH モー ドでシステムを動かすことでオブジェクトは，大型計 算機から SDK-85 で仲介されて, H680TR ボードのメ モリの該当番地からに入れられる。このよらにしてマ イコン内にプログラムがロードされた後に，それぞれ のプログラムにスタートをかければ，実験の制御・計 測が進行する. 当システムのタイプライタには紙テー プ装置も付いているし，それを利用するシステムソフ トもあるので，マイコンにロードされた実験用プログ ラムを紙テープに出して保存して和き，次回からはそ の紙テープから実験用プログラムをマイコンヘロード することがでさる，各ボード上のプログラムへスター トをかけるときとか紙テープ利用のときなどは， S モードまたはSH モードで行なら．SDK-85 ボードが

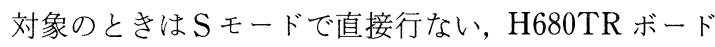
が対象のときはSHモードで SDK-85を介して H680TR へ働さかける。

比較的簡単な実験の制御・計測には, SDK-85 のボー ドだけまたはH680TRのボード1つだけが用いられ る.フル展開の規模の大さい実験のときは, 全ボード (SDK-85 と 2 つの H680TR)が同時に用いられ，ボー ド間で同期がとられ必要な情報が交換されて, 制御・ 計測が進行する.たと艺，1つの H680TR ボードは, テレビカメラと 1 次画像処理装置からの行動の光景を
高次の画像処理し，その時々の行動パターンを計測す ることを専ら分担する。も51つの H680TR ボード は，脳内諸部位からの神経パルス活動のアナログ波形 処理とディジタル・パルスカウントを専ら分担する.ア ナログ波形処理は，比較的長時間に及ぶ連続した神経 パルス波形を A/D 変換しメモリに貯蔵すること，貯 蔵された波形のうち混入不要成分を除去・整形するこ と，貯蔵された波形のドウェルタイム，パルス間イン タバル，パルスハイトなどの分布を求めること, 貯蔵 された波形を $\mathrm{D} / \mathrm{A}$ 変換しモニタ・オシロスコープや

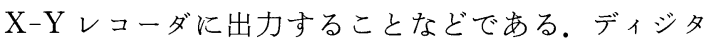
ル・パルスカウントは, $10 \mathrm{msec}, 20 \mathrm{msec}, 50 \mathrm{msec} な$ どの時間間隔ごとに神経パルスの数をカウントし貯蔵 することである.SDK-85 ボードは, 実験の制御・計測 の残りの部分と全体の統合とを分担する。たと六ば，ス キナー箱のバー押しに関する処理, 刺激条件に関する 処理, 強化条件に関する処理, 試行数に関する処理, データの獲得の時期に関する処理などを行なら。デー タの獲得は，たとえば，ある特定条件に合致したバー 押しが出現した時点からさかのぼっての一定時間，ま たは，ある特定条件の行動パターンが出現した時の一 定時間，または，実験者によってサンプルスイッチが 押された時の一定時間などについてなされる。フル展 開の場合は 1 台の “完成品”では扱えない。

得られたデータは, CS または CSH モードで大型計 算機へオンラインで直接送られ, ファイルに保存され, 分析される. 分析結果は, 当システムのタイプライタ や X-Y プロッタに出される、紙数の都合で記述が簡 単になるが，これまでの記述から概略は理解されると 思われる，当然のことであるが，大型計算機との接続 は必要なときだけすればよい。

当システムの用途としては，上記以外に，動物・生 理実験関係の学術文献データ・ベースの利用, ワード プロセッサに類する大型計算機の論文作成のための強 力機能の利用, モデル検討のためのシミュレーション の実行, 大型計算機センター間ネットワーク利用によ る共同研究 (将来) などがある。低経費で高機能, 資 源の有効利用, 強力な大型機の共同利用, システムの 最適設計などの観点から，ワンボード型マイコンの利 用が推奨される。

\section{参 考 文 献}

池田宏明, 山本 博 (1979) インテル 8085 クロスアセ ンブラ—8080クロスアセンブラの拡張. 東京大 
学大型計算機センター・ニュース, Vol. 11, No. 1, 43-46.

石田晴久 (1980) マイコン・ソフトウェア開発のため のクロスソフトウェアの使い方. 東京大学大型計 算機センター・ニュース, Vol. 12, No. 11, 83-89. 石田晴久, 小野芳彦 (1978) マイコン・ソフトウェア

開発のためのクロスソフトウェアの使い方. 東京 大学大型計算機センター・ニュース, Vol. 10, No. 9, 48-59.

石井 嚴 (1979) 動物・生理実験のための東大大型計 算機センターとのオンライン TSS マイクロコン ピュータ・システム. 立教大学心理学科研究年報, 第 $21 \cdot 22$ 号, 34-41.

石井 嚴 (1980) 動物・生理実験のための東大大型計 算機センターとのオンライン TSS マイクロコン ピュータ・システム——その機能と利用法. 立教 大学心理学科研究年報, 第 23 号, 16-26.
McCracken, D.D. (1978) A Guide to $P L / M$ Programming for Microcomputer Applications. Addison Wesley. (石田晴久監訳, PL/M マイク ロコンピュータプログラミング, 1979, 産業図書.) 山本和男（1982）マイクロプロセッサ 68000 用クロス ソフトウェアの使い方. 東京大学大型計算機セン ター・ニュース, Vol. 14, No.1・2, 97-114.

日立製作所, HD $68000 \mathrm{MPU}$ 暫定仕様.

日立製作所 HMCS 6800016 ビット・トレーニングモ ジュール H680TR01 ユーザーズ・マニュアル.

日立製作所 68000 アセンブリ言語マニュアル。

日立製作所 HMCS 6800016 ビット・トレーニングモ ジュールアアセンブラー・テキストェディタ ユーザーズ・マニュアル.

- 1983 年 6 月 受付一 